\title{
NORTH KOREAN REFUGEES IN NORTHEAST CHINA
}

\author{
Andrei Lankov
}

\section{Abstract}

The current crisis in the Democratic People's Republic of Korea has resulted in an explosive increase in the illegal migration of North Koreans to Northeast China. The refugees' presence is seen as a nuisance by all sides involved, but their experience is increasingly influencing domestic policy in North Korea.

The current social and economic crisis in the Democratic People's Republic of Korea (DPRK) has resulted in an explosive increase in the illegal migration of North Koreans to Northeast China. The stream of North Korean refugees is a new phenomenon, but its extent has become one of the factors exercising considerable influence on the situation in the region.

At the same time, the current refugee crisis has a surprisingly low profile in the international media. Northeast Asia has not witnessed an illegal cross-border movement of such magnitude for decades. The refugee crisis directly influences the survival chances of the present regime in Pyongyang and could have a huge impact on the regional political situation. Yet, only when refugees manage to stage a publicity stunt such as the high-profile occupations in 2002 of foreign missions in China does the problem attract a modicum of attention from foreign observers. However, such spectacular actions help only a tiny fraction of the refugees - and adversely influence the fate of the majority.

To a very large extent, the low profile of this potentially explosive problem stems from political pressures from Beijing, Pyongyang, and Seoul. The refugees, estimated at around 100,000, are caught in a complex web of hidden agendas pursued by all sides involved in the crisis and, more broadly speaking,

Andrei Lankov is a Lecturer in Korean Studies at the China and Korea Centre, Faculty of Asian Studies, Australian National University, Canberra. Email: < andreilankov@ yahoo.com>.

Asian Survey, Vol. 44, Issue 6, pp. 856-873, ISSN 0004-4687, electronic ISSN 1533-838X. (C) 2004 by The Regents of the University of California. All rights reserved. Please direct all requests for permission to photocopy or reproduce article content through the University of California Press's Rights and Permissions website, at http://www.ucpress.edu/journals/rights.htm. 
the Korean problem in general. The refugee case also provides us with interesting insights into the changes occurring in Northeast Asia after the end of the Cold War and the power of inertia behind some vestiges of Cold War rhetoric. This article traces the development of the refugee issue and the policies of the countries involved. It also dwells on the likely consequences of the ongoing crisis and its impact on the situation in North Korea.

\section{Refugees in Manchuria}

Few symbols demonstrate the dramatic changes in Northeast Asia as vividly as the growing exodus of North Korean refugees to China in the past few years. Typically, this large-scale border movement, once unthinkable, is seen as a result of the famine that has ravaged North Korea since 1996. To a large extent, this view is accurate. However, the phenomenon of this movement would be impossible without the deep changes occurring inside the North Korean state and transformations of the perception of the "Korean problem" by all of Pyongyang's neighbors.

Until the early 1990s, the border between North Korea and China was a zone of stability and control. From the North Korean perspective, stringent border controls would have been both expensive and unnecessary; an escape to "fraternal" China would not lead to grave political consequences. Indeed, for decades, cooperation between the DPRK and People's Republic of China (PRC) authorities (and their common disregard for such niceties as human rights) ensured that potential defectors would stand little chance to find asylum across the border. In fact, Chinese police were more efficient as a deterrent to defection than the DPRK's own border guards. ${ }^{1}$

There were some exceptions. For example, in August 1956, a group of North Korean leaders, who had taken part in an unsuccessful plot against Kim Il Sung, easily crossed the border to China, where they eventually found asylum. Ironically, at the end of the 1960s, when the Chinese Cultural Revolution was at its height, many ethnic Koreans from China fled to the DPRK, which in those years was a more stable and prosperous society. ${ }^{2}$ However, such incidents remained exceptional.

1. Sufficient to say that out of five known survivors of the North Korean political prison camps who have defected to the South, two were arrested in the 1980s for staying in China without proper permits. An Hyok (often spelled An Hyuk) crossed the border "out of curiosity" in 1986, and Kim T'ae-jin overstayed his visa while visiting Chinese relatives in 1987. Both were apprehended by the Chinese, extradited, and spent some time in the relatively liberal (but still deadly) North Korean Penal Camp \#15 in Yŏdok. See The Hidden Gulag: Exposing North Korea's Prison Camps (Washington, D.C.: U.S. Committee for Human Rights in North Korea, 2003), pp. 31-32.

2. Ch'oe Pyong-guk's story is quite typical in this regard. He was born in China to an ethnic Korean family. In the late 1960s, his family moved to the DPRK; in 1987, when he got himself into trouble with the police, Ch'oe fled back to China. Eventually, he managed to move to Seoul. See Ch'oe Pyong-guk, "Kongsan Tokjae Chach'i-Eso Chayu-Rŭl Kkumkkul Su opsta” [One cannot 
In general, the ethnic composition of Northeast China creates a favorable environment for illegal migration. Two million ethnic Koreans reside in China, and most of these live near the border with the DPRK. Many ethnic Koreans have relatives in North Korea; a small portion are even DPRK citizens - the so-called chogyo. ${ }^{3}$ On the other hand, in the DPRK there are a small number of ethnic Chinese (Chinese: huaqiao). The ethnic Chinese from the DPRK and ethnic Koreans from the PRC were allowed to visit relatives on the other side of the border throughout the 1970s and 1980s, when the governments of both countries were trying to minimize their citizens' contacts with foreigners. The status of these two groups was unique - and was widely used for small-scale trade purposes. This author remembers from his own personal encounters in Pyongyang in the early 1980s that many PRC Koreans and DPRK Chinese were engaged in "shuttle" trade.

However, the stability of the borderline areas began to deteriorate after 1990 , and within a few years the new developments wiped out the old assumptions that had made the balance of the previous decades possible. This resulted from the interplay of several independent factors - although in the final analysis, most were related to the demise of the Communist bloc. The economic crisis in the DPRK has led to a relaxation of government control over both the movement of people and their economic activity. The crisis also resulted in an explosive growth in corruption among North Korean officials-including frontier guards. ${ }^{4}$ China now also provides many more opportunities for business or employment than was the case in the 1980s. Since the establishment of diplomatic relations between China and South Korea in 1992, the border regions have been frequented by South Korean tourists, businesspersons, and missionaries. This led to rapid growth in living standards for those ethnic Koreans who were somehow connected with South Korean economic activities. Last but not least, in reform-era China, the police have somewhat relaxed their grip on the population. Hunting down the growing "floating population" became a

dream about freedom under communist dictatorship], in Puk Han [North Korea], no. 7 (1997) (Seoul), pp. 137-39.

3. In 1997 the number of chogyo was estimated at 6,000. In other words, they comprise some $0.3 \%$ of the Korean population in Northeast China. Song Ch'ǒl-bok, "Chogyo-nǔn Nuguinga?" [Chogyo: Who are they?], Kyŏnhyang Sinmun [Capital and Countryside Newspaper], February 18, 1997, p. 7. Note: all newspaper and most magazine articles cited in this article were retrieved via the Korean Integrated News Database System (KINDS), $<$ http://www.kinds.or.kr $>$. Cited Koreanlanguage newspapers are published in South Korea unless otherwise indicated.

4. There is little doubt that in recent years, border crossing often involves bribing North Korean guards. Testimonies to this are abundant in interviews with refugees. For example, see "Pómjoe Kǔnǔl: 4" [In the shade of the crime: 4], Hangere Sinmun [Korean Nation], August 10, 2002, p. 1; Kim Kyun-mi, "Nǔnhaejin Puk-Chung Kukkyǒng" [The lax border between North Korea and China], Taehan Maeil [Great Korea Daily], March 15, 2002, p. 4. 
mammoth task, one that authorities were unwilling (and often unable) to undertake. Gradual relaxation also meant that the Chinese began to look at the plight of North Koreans, still subjects of a harsh neo-Stalinist regime, with understanding and sympathy and less eagerness to find and extradite them. Together, these phenomena created an important "pull" factor, an essential part of any migration process.

However, the "push" factor is equally important for migration; this was created by developments of the mid-1990s. The catastrophic floods in North Korea led to a crop failure that soon developed into a famine, peaking in 1997-98. It is still difficult to estimate the true scale of this catastrophe, but there is little doubt that the Great Famine of 1996-99 was the worst humanitarian disaster in Korea since the end of the Korean War. The three northern provinces of Yanggang, Chagang, and North Hamgyǒng were hardest hit. According to some estimates, up to one-third of their population starved to death or died of famine-related illnesses. ${ }^{5}$ As a result, refugees began to move to China in 1996 in increasing numbers, although this movement did not attract much attention outside the border area.

It is difficult to estimate the refugees' numbers, partly because of the lack of reliable statistics and partly because this number keeps changing all the time. The most serious attempt to count the refugee population was undertaken during a large-scale study conducted by South Korean sociologists in China between November 1998 and April 1999, when the famine was at its height. The study was commissioned by Choh'ŭn pǒs (Good Friend), a South Korean nongovernmental organization (NGO) that plays a prominent role in helping refugees. According to this study, between 143,000 and 195,000 refugees then took shelter in Northeast China. ${ }^{6}$

After the food crisis in the North eased somewhat, the number of refugees decreased. In 2001-03, most observers believed that at any given moment, about 100,000 North Koreans resided illegally in China. In 2002, a former officer of the Ministry for the Protection of State Security (the North Korean security police) who defected to the South estimated the number of refugees at "some 100,000." He also claimed that internal ministry documents that he had accessed in 1993-98 estimated the annual number of refugees at 50,000.

5. A study conducted among the refugees in China in early 1998 estimated that $32 \%$ of their family members had died in the previous three years. The vast majority of refugees came from northern provinces; thus, this mortality rate largely reflects the situation there. See Kim Kyǒngmu, "Chinan Hae 11-wŏl Ihu Samangja Kŭpjǔng" [Rapid growth in the number of deaths since last November], Hangere Sinmun, March 10, 1998, p. 1.

6. To date, this study remains the best available field research conducted among the refugees, and it is widely cited in numerous Korean publications dealing with the topic. The results of the study were published in 1999 in Tumangang-Ǔl Kŏnnǒon Saramdǔl [People who have crossed the Tumen River] (Seoul: Chǒngdo ch'ulp'an, 1999), p. 27. 
However, these papers also allegedly stated that a vast majority of these refugees did not stay in China for long and soon returned home. Indeed, return migration became a common occurrence in the late 1990 s. $^{7}$ So Tong-man, a well-known specialist on North Korea, also concurs with this figure. In March 2002 , he also estimated the number of refugees at about $100,000{ }^{8}$ Só also remarked that talk of 300,000 refugees, still common in the South Korean press, was "an exaggeration." "Some sources cite a smaller number; the U.S. Committee for Refugees puts the total at $50,000{ }^{10}$ One of the most striking features in the refugees' demographic is the very large proportion of women that made up some three-quarters $(75.5 \%)$ of the total. ${ }^{11}$ Most refugees hide in areas where ethnic Koreans constitute a large proportion of the local population. ${ }^{12}$

Because a majority of the fugitives are women, many of them have married local residents. According to the Choh'ŭn pŏs study, in 1998 some $51.9 \%$ of all refugees (overwhelmingly women) were living with their local spouses. ${ }^{13}$ In most cases, such marriages are arranged via Chinese (Han or ethnic Korean) brokers who are often connected to organized crime. In some cases, these marriage brokers contact young women and their families while they are still in North Korea and arrange their trip across the border. ${ }^{14}$ The girls' decisions,

7. “Ch'oech'o Kukka Kukka Anjŏn Powiby Chidowǒn Ch'ulsin T'albukja Yun Chae-Il” [Yun Chae-Il, the first defector who was a cadre at the Ministry for the Protection of State Security], Chosón Wǒlgan [Korea Monthly], no. 7 (2002), KINDS, <http://www.kinds.or.kr>.

8. Sǒ Tong-man, "Kwajangtoen Puk Ch'eje Wigiron" [Exaggerated views of system crisis in North Korea], Taehan Maeil, March 19, 2002. Dr. So expressed the same opinion in a special report written for the Nautilus Institute, see Suh Dong-man, North Korean Defectors and InterKorean Reconciliation and Cooperation, Northeast Asia Peace and Security Network, Special Report, May 7, 2002, <http://www.nautilus.org/pub/ftp/napsnet/special\%5Freports/dprkrefugees.txt>.

9. Ibid. Statements about " 300,000 refugees" can often be found in South Korean publications. See, for example, Pǒp Ryun, “T’albukja-Edo Hwahae-Ǔi Ongi-Rǔl” [The warmth of reconciliation and the North Korean refugees], Chung'ang Ilbo [Central Daily], September 1, 2000, p. 6.

10. U.S. Committee for Refugees (USCR) Country Report: China 2001, <http://www.refugees. org/world/countryrpt/easia_pacific/2001/china.htm>.

11. Tumangang-ǔl Kǒnnǒon Saramdǔl, p. 21. This figure has been confirmed by other research as well. According to Kwak Hae-ryong, women may comprise as much as $80 \%$ of all refugees. Kwak Hae-ryong, "Pukhan It'al Chumin Ingwon Silt'ae-E Kwanhan Yŏngu” [A study of the human rights situation of the refugees who fled North Korea] in Pyŏnghwa Munje Yǒngu [Study of Peace Problems], no. 1, 2000, p. 261.

12. Tumangang-ǔl Kǒnnǒon Saramdǔl, p. 13.

13. Ibid., p. 24.

14. A female refugee from South Hamgyong Province reported that she had crossed the border in February 1998 with a group of five people, four North Korean women and a broker. All the women had been contacted in the DPRK and agreed to go to China and marry there. The refugee was sold for 3,500 yuan ( $\$ 450)$ to a 30-year-old farmer, with whom she lives quite happily (ibid., pp. 62-63). Another female refugee crossed the border in March 1999. Her group consisted of three girls accompanied by a matchmaker who had also located them in Korea. Ibid., p. 64. 
in such cases, to marry into Chinese society may be seen as voluntary, although the choice is still heavily influenced by the disastrous economic situation in North Korea. However, in many cases female refugees move to China to find employment and food - and then are kidnapped by gangsters who sell them to their future husbands. Sometimes the refugees choose to contact marriage brokers themselves after they have crossed the border. Their experiences in China teach them that opportunities for employment are limited and marriage is the most reliable way to secure their survival.

Whether the woman volunteers for marriage or is kidnapped, the brokers still receive their commission. According to the press, fees range widely, from 1,000 yuan $(\$ 120)$ to 10,000 yuan $(\$ 1,200)$ per woman. It seems that a typical price for a woman in her late 20 s is some $3,000-5,000$ yuan $(\$ 400-600) .{ }^{15}$ The sum is paid by the husband "upon delivery." The entire amount goes to the intermediaries and/or kidnappers: Neither the woman nor her family gets anything, even if they contacted the marriage brokers themselves. ${ }^{16}$ There are occasional references to the sale of young North Korean women to Chinese brothels, but such cases, apparently, remain a rarity. ${ }^{17}$ Most of the "husbands" are people who, for a variety of reasons, e.g., widowers with children, habitual drunkards, drug addicts, or the handicapped, have had difficulty finding a wife by more orthodox methods. In many northeastern villages, the mass migration of young women to the booming cities has resulted in a severe "bridal shortage," such that Korean wives are in high demand.

Because refugees remain in China illegally, they are not permitted to enter into a proper marriage with a Chinese citizen. Such marriages might be symbolically dignified with a traditional ceremony and, thus, be perceived as legitimate to fellow villagers; for official agencies, however, these ceremonies hold no legal value. The Korean women and their husbands live under constant threat that the women might be deported or, at the very least, issued a significant fine of 3,000 to 5,000 yuan ( $\$ 360$ to $\$ 600)$. This author is not aware of a single case in which a female refugee has somehow managed to achieve legal status

15. These cases of kidnapping and the "price range" for Korean women are mentioned by many publications. See, for example, Cho Hyǒng-rae, "T'albuk Yǒin Insin Maemae Kǔksǒng” [The growth of the trade in North Korean women], Chosón Ilbo [Korea Daily], January 12, 1999, p. 27; "Pǒmjoe kǔnǔl: 4," p. 1; and Tumangang-ǔl Kǒnnǒon Saramdǔl, pp. 63, 65, 68, 71, 73.

16. Yim Ǔl-ch'ul, "Yurit'ang Hanǔn T'albuk Yǒsǒng” [North Korean female refugees subjected to mistreatment], in Hangere 21 [Korean Nation] weekly, no. 274, September 9, 1999, KINDS, < http://www.kinds.or.kr > . The relevant testimonies can be found in Tumangang-ǔl Kǒnnǒon Saramdǔl as well.

17. Hwang Ǔi-bong, "Nanmuhanǔn Pukhan Chǒngbo, Beijing-ǔi Nam-gwa Puk" [Chaotic intelligence about North Korea, the North and the South in Beijing] in Sin Tong' $a$ [New East Asia], no. 5 (1999), KINDS, < http://www.kinds.or.kr>. This article mentions that North Korean prostitutes are especially popular among South Korean clients. 
within China: Obviously, this is either difficult or impossible. The situation also adversely affects the legal standing of children born to these unions. To some extent, however, the authorities do take into account the actuality: according to the South Korean press, if a refugee is facing deportation, she is permitted to choose whether to take her children with her or leave them in China (in view of the grim situation in the DPRK, most women prefer to leave their children with their fathers). ${ }^{18}$

Refugees who are not married to "locals" earn their living through casual or unskilled labor. They are typically employed as waitresses or dishwashers in restaurants or cafes, as construction workers, domestic maids, or hired farmhands. Some $18 \%$ of refugees surveyed in the spring of 1999 were paid, at least in part, for their labor, while $12.4 \%$ of the total surveyed labored for bed and food alone. An additional 10.7\% of refugees lived with their Chinese relatives and, we might assume, also worked in the household or family business. ${ }^{19}$ As a rule, the refugees' employers are ethnic Koreans. Because the refugees live in the PRC illegally, their wages remain well below those of local residents - a phenomenon well known to illegal migrants of all ages the world over. The farm laborer, for example, typically receives 5 to 10 yuan (about a dollar) per day, in addition to bed and food. In many cases, the refugees are not paid money at all, receiving merely room and board. ${ }^{20}$ Nevertheless, even this modest income represents a considerable bonus to the impoverished North Koreans.

Nor does employment of a refugee come without risk, being a breach of local law. The authorities impose on the employers large fines, up to 5,000 yuan (\$600) per infringement. ${ }^{21}$ However, judging from anecdotal evidence, the attitude toward the refugees of the local population, both Han Chinese and Korean, is generally sympathetic. In their interviews, refugees frequently describe how local residents - in spite of official restrictions - supplied the fugitives with food and clothing, helped them reach their destinations, or hired North Koreans even when their labor was not necessary. The following stories have been chosen virtually at random and describe the largely benign reception afforded refugees by the local population in 1996-99: "All four of us [North

18. Kim T'ae-gyǒng, "Maŭl, Sansok T'umangsik Kǒmgó” [Casting-net style roundups in villages and mountains], Hangere Sinmun, July 9, 1999, p. 14.

19. Tumangang-ǔl Kǒnnǒon Saramdǔl, p. 25.

20. Ha Chong-dae, “Ttǒdonǔn T'albukja T'aep'ung-Ǔi Nun: Haepǒp Angae Sok” [The center of the refugee storm: No solution in sight], Tong'a ilbo [East Asia Daily], August 17, 2002, p. 10; Tumangang-ǔl Kǒnnǒon Saramdǔl, p. 23.

21. Kim T’ae-gyǒng, "Maǔl, Sansok T'umangsik Kǒmgǒ,” p. 14; Yi Sǔng-han, "Songhwahamyǒn Chugóyo" [I'll die if I am deported], Kukmin Ilbo [Citizens' Daily], April 8, 2000, p. 26. Hangere Sinmun also reports that Chinese authorities pay 500 yuan $(\$ 60)$ as a premium for the denunciation of a fugitive. 
Korean women who had just crossed the Tuman River] approached one of the houses. The gates were closed, but the owner lit lights and invited us to enter. We told him about our situation, and [he] replied that since this was the case, we could have a meal and stay for the night." In another example, a family of refugees reached a remote village where they could enjoy relative safety: "There was an empty house [in the village], and the villagers supplied us with clothes, soy sauce, salt, and vegetables." 22 In the last few years, however, when refugees have been fleeing more for economic gain than from near-certain death (as was the case in 1997-99), the attitude toward them has cooled considerably. ${ }^{23}$

In most cases, the decision to flee to China stems from purely economic considerations. The refugees - at least, the majority of them - are not political dissenters, in any sense. However, the large, illegal community of North Korean refugees has unwittingly created a major political problem for the three principal countries involved in the crisis: China, South Korea (ROK), and the DPRK.

\section{Undesirable Brethren}

The current crisis also sheds new light on Seoul's changing approach to the "North Korean problem." At first sight, defection to South Korea would be the most logical next step for these refugees. Indeed, Cold War logic would make us expect that such refugees would meet an enthusiastic welcome in the South, as was the case in the 1980s, when successful defections were very rare. The same expectations are still common among North Koreans, who often assume that they will be granted passage to Seoul as soon as they reach a South Korean embassy or consulate. ${ }^{24}$ However, the world has changed and nowadays the South Korean approach to the refugee problem is driven by a set of pragmatic considerations. At the same time, the constraints of domestic politics prevent Seoul from revoking its rhetorical stance, constructed during the Cold War era. This creates a peculiar, sometimes bizarre, situation.

Indeed, only a small portion of the refugees, about 1,000 , migrate to the South each year. ${ }^{25}$ The Seoul government is remarkably unwilling to accept

22. Tumangang-ǔl Kǒnnǒon Saramdǔl, pp. 67, 94.

23. For remarks to this effect made by one of the refugees, see "Pyǒnghwahanŭn Pukhan, Kŭ Ǔiminǔn Muǒsinga?" [Changing North Korea: What does it mean?], Keys (a Korean-language bimonthly magazine), no. 7-8 (2002), < http://www.nknet.org/kr/keys/lastkeys/2002/26/03.php>. This recent change of attitude is addressed at some length in Hangere Sinmun, August 5, 2002, p. 1: "Pǒrǒjinǔn T’ǔmsae: T'albukja-Chaejung Tongp'o Kaldǔng-Ǔi Ssak" [The growing gap: Seeds of discord between the refugees and Chinese-Koreans].

24. A North Korean retired officer who fled to China with his wife wrote: "I thought that the defection to the South would be easy, but it was not the case." See Pak T'ae-yǒng, "Mije ch'imryakja-dǔl Han Nom-do Namgim-ǒpsi ǒps'ae'pǒriyaji”" [Let's destroy the U.S. imperialist aggressors up to the last man!] in Puk Han [North Korea], no. 6 (2001), p. 170.

25. According to the National Intelligence Service, 1,139 defectors arrived in the South in 2002. In 2001, there were 583 defectors, and in 2000, they numbered 312 . An overwhelming 
them and this position is reflected by South Korean agencies in China. If a refugee manages to contact a South Korean consulate or embassy, he or she will not find support there unless the situation is deemed exceptional.

Ironically, some who have been denied assistance would have been seen just a few years previously as a god-given propaganda gift. In 1996, for example, the South Korean Embassy in Beijing was visited by a family of six whose father, an exemplary "shock worker," had been granted the rare honor of having his picture taken with Kim Il Sung, the Great Leader himself. The diplomats at the time could only advise the family that they were unable to do anything for them and wished the would-be defectors good luck! But they had no such luck - they were arrested, deported back to the DPRK, and severely punished there. ${ }^{26}$ A 36 -year-old military officer from an elite security unit who fled to China in 1996 spent 1996-2002 repeatedly applying for permission to migrate to the South. He contacted the South Korean Embassy a few times but every time, diplomats advised him to "be patient and wait." ${ }^{27}$

Needless to say, less well-positioned people are even less fortunate. The South Korean press is full of stories about defectors who approached South Korean embassies or consulates but were turned away. ${ }^{28}$ One defector told a South Korean journalist: "When I first fled the North I thought that it would be easy to go to South Korea. With the help of ethnic Koreans, I arrived in Qingdao [in eastern China] in August 1996. But at the Korean Consulate on which I had pinned all my hopes [I] was told: 'Under the present circumstances, this is difficult.' [I felt like] the heavens collapsed." ${ }^{\text {29 }}$ Another defector (who eventually reached his destination) told a South Korean weekly: "In the early 1990s, when I was in China, I visited the Embassy three times. I knelt there and begged them to save my life but received only humiliation." ${ }^{30}$ The present author is not aware of any story of a "non-connected" refugee whose trip to Seoul was arranged by South Korean officials. Obviously, only people who

majority of these moved to the South via China. See Yi Hun-gi, "Kukunae Ipkuk T'albukja 5,000 Myŏng Nŏmŏsŏ" [The number of North Korean defectors in the South exceeds 5,000], Tong'a Ilbo, November 17, 1999, p. 8.

26. "Ch'oech'o Kukka Kukka Anjǒn Powiby Chidowǒn."

27. Ha Sǒng-bok, "Hanguk Taesagwan-Ǔi Mangmyǒng Sinch’ǒng Moksal” [The Korean embassy remained silent when I asked for asylum], Hangere Sinmun, May 24, 2002, p. 1.

28. For a number of such stories, see Kim Mi Yǒng, "T'albuja-dǔl Hoego 'Nae-Ga Chu-Jung Hakguk Taesagwan-E Tǔrǒkassǔl Ttae'/Towajulsu Ǒpsǔni Yǒgi-Esǒ Nagara!” [The defectors recollect: "When I arrived at the Korean Embassy"/'We cannot help, get out of here!'”], Chosǒn Ilbo, May 15, 2002, p. 55.

29. Kim Hwa-sǒng, "Hanguk Taesagwan Sǒulhaeng Antowajuǒ" [The Korean embassy does not assist in passage to Seoul], Tong'a Chugan [East Asia Weekly], no. 166, January 7, 1999.

30. Ko Chae-yǒl, "Haengbokhan 7 In, Purhaenghan 30 Man" [7 are happy, 300,000 are not], Sisa Chŏnal [Current Affairs Magazine], no. 611, July 11, 2001, KINDS, <http://www.kinds.or.kr>. 
represent a significant propaganda value (or have had access to important intelligence) can count on such assistance, as was the case of Hwang Changyǒp, a former North Korean chief ideologist who in 1997 defected to the South via China.

Another privileged group are refugees who have relatives in South Korea or in Western countries. If these relatives are able (and willing) to provide the refugees with money, many of their problems can be solved. In most cases, the relatives pay smugglers who arrange the refugees' trip to South Korea. Once in the South, the refugees turn themselves over to the authorities. Because they are, technically speaking, citizens of the ROK, extradition is out of the question, so they receive the full rights of a South Korean citizen, and even modest financial aid to which all defectors are eligible. It was estimated in 2000 that more than half of all defectors had South Korean relatives. These relatives paid brokers, whose help was crucial. ${ }^{31}$ Nevertheless, the expenses involved are quite high, typically about $\$ 10,000$, and only a fraction of refugee relatives are willing to pay such a sum. ${ }^{32}$

The South Korean reluctance to accept refugees is based on several pragmatic considerations. One is the government's unwillingness to create problems in its relations with China. The PRC carefully maintains neutrality in the inter-Korean conflict and does not wish to become a transition zone for unruly crowds of refugees heading for Seoul. Indeed, this explanation is often cited by diplomats in their talks with asylum seekers. Some refugees who take these explanations at face value decide to move to countries in Southeast Asia or Mongolia where, they figure, South Korean diplomatic missions would be more supportive. Such a trip is arduous and risky. Quite often in the South Korean missions in Hanoi and/or Bangkok, refugees encounter the same attitude as in Beijing. ${ }^{33}$

Another often-cited reason for the less-than-enthusiastic welcome of aspiring defectors is that South Korean officials are also wary of ethnic Koreans from China, who might try to pass themselves off as North Koreans in order to

31. Yun In-jin, Pukhan T'aljumin-ǔi Ihae-wa Chawonpongsa [Voluntary service and support of North Korean refugees] (Seoul: Koryǒ taehakkyo, 2000), p. 10.

32. "Making a successful defection takes a lot of money and requires the involvement of many people, including North Korean officials and Chinese brokers," according to Cho Dong-young, chairman of the Korean Assembly for the Reunion of Ten Million Separated Families (KARTS). See Kim Ji-ho, "Defectors from North Not Always Welcomed by Southern Relatives," Korea Herald, January 19, 2000, p. 3.

33. For a discussion of the difficulties experienced by North Korean refugees in Southeast Asia, see Ky Su-jŏng, "'Bet'ŭnam rut'ü'-ŭi nunmul” [Tears of the "Vietnamese route"] in Hangere 21, no. 254, April 22, 1999. For remarks to the same effect, see " 25 in-ǔi t'albuk, nugu-ǔi chakp'um inga?" [The escape of the Twenty-five: Whose achievement?] in Sisa Chónal, no. 648, March 28, 2002, KINDS, <http://www.kinds.or.kr>. 
get access to ROK citizenship. ${ }^{34}$ These worries are justified, at least, in part. In September 2002, the South Korean government reported that from 1999 to 2002 there had been 15 known attempts of Chinese citizens passing themselves off as North Koreans. ${ }^{35}$

Nevertheless, it appears that the major, if rarely stated, reason behind Seoul's passivity is a tacit understanding that refugees, who are largely uneducated peasants, have little hope of successfully adjusting to South Korean society. Once in South Korea, in all probability they will become an additional source of social tension and require support through the welfare system for the rest of their lives. There is already some evidence of this: Among those North Korean defectors of working age who have managed to reach the South, about $50 \%$ have not been able to find full-time employment, in spite of South Korea's traditionally low unemployment rate, $3 \%-4 \%$ in $2002-03$. Among defectors who have found a job, $80 \%$ earn less than one million won (US\$900) per monthhalf the national average. ${ }^{36}$ Therefore, refugees are likely to become a burden on the South Korean government.

However, we can identify, with reasonable confidence, another, somewhat paradoxical, reason for the ROK's reluctance to help the refugees: Seoul does not want to destabilize its ex-enemy. A large-scale exodus to the South would likely cause a serious political crisis in Pyongyang, leading, in all probability, to a "hard landing" for the North Korean regime. This is exactly the scenario that South Korean diplomacy strives to prevent; in recent years, "German-type unification" has been seen as a nightmare, to be avoided at all costs.

A great deal of ideological and legalistic inertia also contributes to the ROK's reluctance to assume responsibility for the refugees. For decades, the Seoul government has insisted that it is the only legitimate government of all Korea.

34. This is the reason why all defectors who manage to cross into the South are normally required to produce North Korean identification. The inability to produce such proof of origin might mean rejection, even on South Korean soil. Kim Yong-hwa, a former North Korean officer who fled to China in 1988, was rejected by the South Korean missions in China and Vietnam. In 1995, he was extradited by the South Korean immigration service after he had secretly arrived on the South Korean coast on a small boat. The reason for the rejection was that he carried only Chinese identification and could not present documents proving his North Korean origins. Kim's misfortunes became a major media issue. As usual, publicity helped: To avoid embarrassment, the Seoul authorities allowed him into the country. Kim's story has been retold a number of times, e.g., Yi Yǒng-jong, "14 Nyǒn Yurang Kim Yong-Hwa Ssi 'T'akbukja' Injǒngtoel Tǔs” [Kim Yong-hwa is recognized as a 'North Korean defector' after 14 years of wandering], Chung'ang Ilbo, March 2, 2002, p. 34 .

35. Chǒn Sǒk-un, “1999 Ihu Wijang T’albukja 15 Myǒng Chǒkbal” [Since 1999, 15 pseudorefugees have been unmasked], Kukmin Ilbo, September 16, 2002, p. 2.

36. Pak Yun-ch'ǒl, “T’albukja 1000 Myǒng Sidae: Ǒttǒk'e Salgo Issna?" [The era of 1,000 refugees: How do they live?], Tong'a Ilbo, November 17, 1999, p. 8. 
Therefore, all North Koreans are, by definition, citizens of South Korea who theoretically enjoy the right of protection. An open renouncement of this decades-old position would be fraught with numerous ideological and legal problems because it would imply the renouncement of the long-standing fiction of "one Korea." Such a turn of events is likely to upset the entire South Korean political spectrum.

This contradiction between official legalistic rhetoric and the actual policies of the countries involved was exposed starkly in late 1999 when the fate of a handful of North Korean refugees facing extradition to Russia briefly made the refugee problem a much-discussed issue within Korea itself. In October 1999, Minister for Unification Lim Tong-won told the National Assembly that the "government is ready to accept all North Korean refugees, if they want to emigrate to the South." He also added: "It is the basic principle of the Seoul government to welcome all North Korean refugees. .. . [I]t is in line with the Constitution to accommodate [North Korean] refugees." ${ }^{37}$ This statement once again expressed the traditional position of the ROK government, which has asserted that protection of all North Koreans is its legal duty. However, the Ministry for Unification immediately "clarified" the ministerial statement. A senior official there explained to reporters that the minister's remarks referred to a "group of North Koreans who had wrapped up all the necessary procedures for entry into South Korea with the nation's overseas embassies." Such a "clarification" effectively rendered the minister's statement meaningless, as it excluded virtually all refugees in China, none of whom had valid passports (and who often had no identification documents at all), thus making it impossible for them to "wrap up" any entry.

Over the last two years, South Korea's press and NGOs have widely discussed plans to create-with Chinese endorsement-special refugee camps, which could be located in China or adjacent countries, such as Mongolia or Thailand. From the South Korean point of view, these would be a cheap solution to the problem. ${ }^{38}$ There is little doubt that supporting the refugees in such camps would be much less expensive than bringing them to South Korea. The adoption of such a policy would allow Seoul to mute criticism from the domestic opposition without taking on an excessive financial burden or renouncing established ideological fictions. However, a prerequisite for such a solution

37. Both Yim Tong-won's statement and its "clarification" attracted much attention and were reported by all Korean media. Here, we use the English wording of the Korea Times, which reported both the ministerial statement and its effective withdrawal in the same October 18, 1999, issue, albeit in different articles (Kim Yong-bom, "Korea to Accept All NK Refugees," p. 2 and Son Key-young, "Seoul Lacks Practical Means to Accept N. Korean Defectors," p. 3.

38. Such plans have been widely discussed in the South Korean press. See, for example, Kim Chae-bon, "T'albukja p'Inanch'o Maryǒnhara" [Give North Korean refugees a place to shelter], Munhwa Ilbo [Culture Daily], September 6, 2002, p. 7. 
would be Chinese willingness to guarantee the North Koreans refugee status, a step Beijing is not willing to take.

\section{Beijing's Choices}

The PRC government has its own stakes in the problem. First of all, Beijing sees the North Koreans as a potentially troublesome nuisance. When, in August 2002, the Chinese ambassador to South Korea was interviewed by the Taehan Maeil [Great Korea Daily], an influential South Korean newspaper, he replied to a question about refugees, "Since the economic situation in North Korea recently deteriorated, some North Korean citizens have illegally crossed the border to China. Taking into consideration the reasons for their arrival in China as well as international law, they cannot be seen as 'refugees'. We will protect order on our borders, while treating them according to humanitarian political principles." 39 The same definition of the North Koreans as illegal immigrants (rather than refugees) has been reiterated by a number of Chinese officials on different occasions. ${ }^{40}$

Their underlying concerns are easy to identify: If Beijing grants the North Koreans much-coveted refugee status, this will have two important consequences. First, China will have to provide them some aid. Currently, the refugees are fending for themselves and do not cost the central authorities a yuan; in general, their cheap labor might be even beneficial to the Chinese economy. The second, presumably much more important, reason for the Chinese reluctance to treat the North Korean migrants as refugees is political: Such treatment might encourage further defections, which would probably lead to destabilization of the North Korean regime. After all, the dramatic disintegration of East Germany occurred when hitherto "fraternal" Hungary refused to prevent East Germans from crossing into its territory and seeking asylum in West Germany. No doubt this lesson of history is not lost on Beijing.

For ordinary refugees, the only way to enter the South is to attract a modicum of attention to themselves. In the late 1990s, this usually implied cultivating relations with the South Korean press, since media involvement and the associated publicity occasionally helped. Recently, the refugees, or, more correctly, the NGOs involved with them, have discovered a much more efficient way to grab media attention. They stage semi-symbolic takeovers of foreign diplomatic missions and agencies. Quite often the foreign press is informed of

39. “Chung Taesa Int'obyu: 2 " [Interview with the Chinese ambassador: 2], Taehan Maeil, August 22, 2002, p. 5 .

40. See, for example, a lengthy interview of Zhu Liang, former head of the International Department of the Communist Party of China's Central Committee, in the October 2002 issue of Wolgan Chungang [Central Monthly]. Zhu sometimes describes the refugees as "illegal trespassers" (Korean: pulpop wolgyǒngja). 
the forthcoming "attack," and such events unfold in front of foreign camera crews and journalists, thus ensuring worldwide publicity. The remarkable sophistication of these events (leaflets in good English, presence of foreign camera crews, etc.) is obviously a result of heavy involvement by foreign NGOs. ${ }^{41}$

Sometimes the planners of such break-ins demonstrate remarkable sophistication; this is necessary, because embassies are heavily guarded in China. For example, during the "takeover" of the Canadian Embassy on September 29, 2004, the defectors, dressed as construction workers, placed three large ladders against the embassy wall and climbed it before the guards noticed that something was going on. By the time the guards raised alarm, 44 North Koreans were inside the embassy compound. ${ }^{42}$

The first such occupation took place in June 2001, when seven North Koreans, all members of the same family, took refuge in the United Nations High Commissioner for Refugees (UNHCR) office in Beijing. The real "high season" of intrusions began in 2002. From March to September, events were staged in seven foreign missions: the embassies of South Korea, Canada, Germany, Albania, Spain, and the U.S., as well as in Japanese and American consulates in Shenyang and in a German international school.

Generally, this strategy works. Once South Korean diplomatic officials are faced with such a crisis, they have no choice but to arrange for the refugees' removal to Seoul, even though, under less-dramatic circumstances, embassy staffers would barely deal with them. In most cases, the sides involved appear to have done their best to solve the crisis as soon as possible, apparently to minimize publicity and press coverage. In this regard, the interests of China, the ROK, and the DPRK hardly differ. As of late December 2002, some 160 North Koreans are known to have successfully used foreign missions for their escape to the South. ${ }^{43}$

The occupation of foreign missions may be a good publicity stunt that helps those directly involved in such bold actions. However, successful occupations have their downside: They adversely influence the position of the majority of refugees. Needless to say, the Chinese authorities did not look at the occupations favorably. The dramatic - and dramatized - events in Beijing underlined the economic impotence and political instability of China's ally, as well as

41. The most prominent role belongs to Norbert Vollertsen, a German medical doctor who once worked in North Korea. In May 2002, Dr. Vollertsen described his strategy frankly to South Korean journalists: "I came to recognize that creating big events covered by the global media is the only way to help resolve the defector issue." See Shim Chae-yun, "NGOs Offer Conflicting Prospects for Defection," Korea Times, May 17, 2002, p. 3.

42. "Daring Asylum Bid in Beijing," CNN report on September 29, 2004, < http://edition. cnn.com $>$.

43. "Beijing Tǒgil Hakkyo Chinip T'albukja 4 Myǒng Sǒul Haeng” [Four refugees who broke into the German school in Beijing are moving to Seoul], Taehan Maeil, December 25, 2002, p. 2. 
raising doubts about the Chinese authorities' ability to control their own capital. Therefore, from September 2002 onward, security measures around foreign embassies in Beijing were stepped up and in December, the Chinese police began large-scale hunts for refugees in the three provinces of the Chinese Northeast. This effort was known as the "hundred-day battle," because it was meant to last from mid-December to mid-March. The initiative obviously came from the Chinese side, even if the North Korean authorities were also quite eager to participate by sending their police officers across the border. According to press reports, during late December and early January alone, the massive searches led to the arrest and subsequent extradition of some 4,500 refugees. ${ }^{44}$

The spectacular refugee actions of 2002 would have been impossible without the help of international and South Korean NGOs. ${ }^{45}$ Therefore, the Chinese authorities began to harass the refugees' advisers. In December 2002, in Jilin Province, a group of foreign and Chinese nationals stood trial for "people smuggling." The group included a South Korean pastor, a Korean-American, four North Korean citizens, and 12 Chinese nationals (the latter being ethnic Koreans). All these individuals had allegedly been involved in staging the escapes of North Koreans. ${ }^{46}$ It is noteworthy that their arrest and subsequent trial did not receive much coverage in the Seoul press, reflecting the ambivalence of South Korea's approach to the refugee issue.

To some extent, North Korea's reaction to the crisis reflects the same gap between the inertia of Cold War rhetoric and Pyongyang's new pragmatismdriven policies, a gap that is also obvious in Seoul's reaction. Until the

44. Cho Sŏng-jin, "Chung, T'albukja Taegǒ Kangje Hwangsong" [Large-scale deportations of North Korean Refugees in China], Syegye Ilbo [World Daily], January 10, 2003, p. 3; Kim Chaebong, "Kkǔlyǒkanǔn T'abukja" [The refugees who are taken away], Munhwa Ilbo, February 5, 2003, p. 7. The timing of the entire operation might be related to the fact that during these three months, the rivers are frozen, making crossing even easier.

45. Among major institutions involved in providing North Koreans with assistance, two deserve mention. Helping Hand Korea (HHK) makes a clear statement on the front page of its official website: "From 1998, HHK diversified its assistance activities to North Korea by giving special emphasis to direct aid for North Korean refugees in China and, in extraordinary circumstances, coordinating logistical support for their escape to third countries." See $<$ http://www.familycare.org/ network/p01.htm>, accessed October 9, 2004. Also notable are the Japanese NGO Life Funds for North Korean Refugees and a number of South Korean groups, often associated with religious organizations.

46. “Chung, T’albuk Alsǒnhoe 7 Myǒng Chǒngsik Chaep'an Ch'aksu” [Seven people are standing trial for helping North Korean refugees], Kukmin Ilbo, December 7, 2002, p. 2. The leader of the group, pastor Ch'oe Pong-il, was condemned to nine years' imprisonment. See Hong Inp'yǒ, "T'albuk Chiwon Hanguk-in 9 Myǒng Chungsǒ Sugam Chung" [Nine Koreans are in Chinese prisons for helping [people] escape from the North], ibid., March 20, 2004, p. 6. Ch'oe was released after two years in prison and returned to Seoul in September 2004. Han Chang-hŭi, "Chung-sǒ P'ullyǒnan Ch'oe Pong-il Moksa" [Pastor Ch'oe Pong-il released from a prison in China], ibid., September 24, 2004, p. 8. 
mid-1990s, DPRK authorities treated an attempted border crossing as a serious political crime. However, since the beginning of the Great Famine around 1996, North Korean authorities have dramatically softened their policy toward fugitives, likely because of their large numbers and the obvious lack of political motivation behind their behavior. Illegal border crossings are now treated as a relatively minor offense, even if the authorities do not recognize this openly. Although occasional reports of executions of apprehended defectors do surface, these appear to be the exception and often involve those who (with or without reason) are accused of espionage or subversive activities. The majority of the defectors who are apprehended by border guards or extradited from China are detained for only a short term, normally, a week or two. During their detention, they are subjected to police interrogation. If they are not found guilty of any serious offense, they are sent to "labor reeducation," a period of forced labor lasting a few months. According to a recent study that summarizes available data on the treatment of deportees, an astonishing $40 \%$ of them return to China after their release from detention. ${ }^{47}$

\section{In Lieu of Conclusion: The Refugees and the Future of the North Korean State}

The majority of refugees do not intend to enter South Korea. Their major purpose is, essentially, survival: They wish to avoid starvation and survive until the end of North Korea's "difficult times." Many refugees avail themselves of any opportunity to send money or goods back home. Occasionally, they make home visits themselves, crossing the border to the North, spending some time with their families and then returning to China. The mode of living of such refugees might be called a hybrid of shuttle trading, smuggling, and fugitive status. In this regard, the Chinese side does have good reason for describing them as "illegal migrants," not "refugees." As early as 1998-99, internal papers of the North Korean police reportedly stated that a majority of refugees eventually come back after a brief sojourn in China. ${ }^{48}$

Why did the Stalinist DPRK, normally not known for its tolerance of unauthorized interaction with the outside world, choose to be so lenient toward its fugitives? Perhaps the South Korean unwillingness to accept refugees persuaded Pyongyang that the political risks involved are relatively low. The exodus of more restive portions of its population might save the bankrupt state from the troublesome necessity of caring for people it is unable to feed anyway. Tolerance also may be seen as a safety valve, because people who flee the

47. "T'albujadŭl-ǔi T'alch'ul Kwajŏng-gwa Songhwan Hu-ǔi Unmyŏng," Keys, no. 6 (2002), $<\mathrm{http}$ ://www.nknet.org/kr/keys/lastkeys/2002/25/03.php >.

48. See "Ch'oech'o Kukka Kukka Anjǒn Powiby Chidowǒn." 
country are less likely to cause political unrest. Refugees even remand some foreign currency, which is sorely needed by Pyongyang.

Whatever the reason for the current degree of tolerance, the refugee crisis is likely to have serious consequences. The "East German scenario" of defections triggering a regime's collapse does not appear particularly likely, but cannot be ignored completely.

There is no doubt that in the long run, the refugees will profoundly impact North Korean society. The refugees have now become the first statistically significant group of North Koreans to have firsthand experience abroad. For decades, the North Korean authorities have gone to great lengths to ensure that no ordinary citizens would have access to unauthorized information about foreign countries, particularly about South Korea. However, the refugees are breaking this self-imposed information blockade. They have seen the results (both good and bad) of market reforms in China and are painfully aware of North Korea's backwardness and poverty. They bring back small transistor radios that have spread across the country in recent years. This is important, because all privately owned radios in North Korea have been required to have fixed tuning, thereby only permitting listeners to receive the few official broadcasts. Returned refugees also have some inkling of South Korea's prosperity and some of the younger ones have even surfed South Korean Internet sites. They are less likely to believe official propaganda. And they are too numerous to be silenced or isolated. ${ }^{49}$

Internationally, the refugees constitute a considerable nuisance to the authorities of at least three countries. Sadly, in fact, the refugees, whose only goal is survival (or, perhaps, a slight improvement in their lot) have become victims of the real or perceived political interests of Beijing, Pyongyang, and Seoul.

For Pyongyang, the refugee problem is a reminder of the disastrous social situation in the country. It is impossible to pretend that, as the propaganda suggests, North Korea is a "Paradise on Earth," if so many citizens attempt to escape from its supposedly happy and affluent life. Moreover, it is highly likely that refugees are sometimes used by the South Korean intelligence services, which thereby, for the first time since the early 1970s, have acquired a means

49. On the spread of small radios and interest in South Korean broadcasts, see "T'albukja $67 \%$ Puk-e issǒssŭl ttae Namhan Radio Ch'ŏngch'wi” [67\% of all defectors listened to the South Korean broadcast while in the North], Tonga Ilbo, February 28, 2003, p. 49. A collection of interviews with defectors conducted in Northeast China in 2003 includes a number of interviews with people who cross the border regularly. "Puk-chung kukkyŏng choyŏk-ŭl kada" [Traveling in the areas near Sino-Korean border], Keys, no. 1 (2004). On the use of Internet facilities by North Koreans in China, see Han Chang-hŭi, "Puk silsang alliryŏ . . . T'albukja homp'i kaesŏl" [To tell about the real situation in the North . . . A defector establishes a home page], Kukmin Ilbo, July 6, 2004, p. 8; Yi Mi-suk, "Kasŭmi Ullin T'albukja e-meil" [An emotional e-mail from a defector], Munhwa Ilbo, May 28, 2002, p. 2. 
of infiltrating the North. Last but not least, the refugees have created a significant breach in North Korea's carefully maintained wall of isolation from the outside world.

The Chinese authorities are not happy about the presence of many illegal immigrants in their country. Apart from the economic and social problems refugees cause (or may cause) in the cities of Northeast China, their presence creates a number of diplomatic problems and adversely influences relations between China and the two Koreas. China also worries about the stability of North Korea, which serves as a strategically important buffer between the Chinese Northeast and the U.S. forces in South Korea. The ideological affinity between the two states may also play a part in the Chinese stance: It does not hurt Beijing to have another Communist regime nearby.

The South Korean authorities also find themselves in an uneasy position. On the one hand, they are expected to do something for the refugees who, as they themselves insist, are their compatriots and even, theoretically, their citizens. On the other hand, South Korea is reticent about playing host to the refugees because, as Seoul understands only too well, such a humanitarian act in the long term will be very costly. In addition, Seoul wants to avoid unnecessary problems in its relations with China, an important trading and political partner. Lastly, in recent years South Korea has come to fear a German-style unification, which is seen as an exceedingly costly option, to be avoided if possible. Therefore, Seoul is not willing to support any developments that might lead to the collapse of its traditional adversary.

Surprisingly, with regard to the defectors, the interests of the three countries do not differ. All three want the defectors to remain invisible and not create much political trouble. Judging by the reaction of the international media to the defections, the three countries have been reasonably successful in achieving this goal: Despite the occasional story, as with the intrusions into foreign missions in Beijing, one of the largest international migrations in the post-war history of the region remains essentially unnoticed by world media. Among the array of potential protectors of these troubled people, perhaps only a handful of NGOs really care about the suffering of the refugees, instead of focusing on the diplomatic nuisance or political embarrassment they may create. 